\title{
Application of Immediate Loaded Mini Dental Implants for Retaining Mandibular Overdenture Prosthesis in Edentulous Patients: A Systematic Review
}

\author{
Abdulaziz A. AlHelal (D)
}

check for updates

Citation: AlHelal, A.A. Application of Immediate Loaded Mini Dental Implants for Retaining Mandibular Overdenture Prosthesis in Edentulous Patients: A Systematic Review. Appl. Sci. 2021, 11, 10724. https://doi.org/10.3390/app112210724

Academic Editor: Paola Gandini

Received: 15 October 2021

Accepted: 5 November 2021

Published: 13 November 2021

Publisher's Note: MDPI stays neutral with regard to jurisdictional claims in published maps and institutional affiliations.

Copyright: (C) 2021 by the author. Licensee MDPI, Basel, Switzerland. This article is an open access article distributed under the terms and conditions of the Creative Commons Attribution (CC BY) license (https:// creativecommons.org/licenses/by/ $4.0 /)$.
Department of Prosthetic Dental Sciences, College of Dentistry, King Saud University, Riyadh 11545, Saudi Arabia; abalhelal@ksu.edu.sa; Tel.: +966-580703308; Fax: +966-14678639

\begin{abstract}
The aim was to systematically review the efficacy of immediate loaded mini dental implants (MDIs) to retain mandibular overdentures in regards to survival rates of MDIs, peri-implant clinical and radiographic tissue response and associated factors. A literature search of English literature was performed using Google Scholar, Scopus, Web of Science, MEDLINE (OVID), EMBASE, and PubMed using predetermined inclusion criteria. Specific terms were utilized in searching from the inception of the respective databases up to April 2021. The focused question was: Do immediate loaded MDIs supporting mandibular overdentures present favorable treatment options for prosthetic rehabilitation? The 11 articles included in the present review examined 349 patients (198 males +171 females [66.65 \pm 6.28 years]) in which 1190 MDIs were placed to retain mandibular overdentures. The mean follow-up duration was 24.5 months. The cumulative survival rate of MDIs was $97.3 \%$. The mean scores of plaque index, gingival index, probing depth, and bleeding on probing ranged between $0-3,0-3$, and 1.203-1.76 respectively, whereas the mean marginal bone loss values ranged from $0.42 \pm 0.56 \mathrm{~mm}$ to $1.26 \pm 0.64 \mathrm{~mm}$. The results identified that the application of immediate loaded MDIs to retain mandibular overdentures are a potential treatment modality for edentulous patients.
\end{abstract}

Keywords: mini implants; overdenture; prosthodontic rehabilitation; survival rate

\section{Introduction}

For years, edentulous patients have had no other option than conventional dentures for re-establishing their oral function [1]. Loose and unstable dentures with a compromised function is a common complaint in complete denture patients. [2]. During the previous decades, there has been a revolution regarding rehabilitation treatments for edentulous patients. The progress in dental implants and osseointegration formulated a new set of possibilities other than the conventional treatment with complete dentures, even for individuals presenting parafunctional activities [3]. A conference group, after much debate, established that the ideal rehabilitation model for an edentulous patient should be a complete maxillary denture and a two-implant retained mandibular overdenture as an antagonist [4].

A major limitation to the procedure of implant placement is the deficiency of bone tissue to support and sustain the dental implant. As per Atwood classification, alveolar ridge atrophy and resorption take place in two dimensions: horizontal and vertical. The alternative in such scenarios is to carry out bone graft surgery for increasing bone height and volume. Mini dental implants (MDIs) are indicated in horizontally atrophied alveolar ridges having inadequate bone width and adequate bone height. Usually, elderly patients are not willing to undergo so many surgical procedures and may refuse dental implantretained rehabilitation [5-12].

MDIs (1.8-2.9 $\mathrm{mm}$ in diameter) have been indicated to be a surgical alternative to conventional dental implants for patients with narrow alveolar ridges [13-18] The Glossary of Oral and Maxillofacial Implants (GOMI) has defined MDIs as "dental implants fabricated 
of similar biocompatible materials as other dental implants but of smaller dimensions" [19]. They present a single body system with a ball-type attachment incorporated and usually are placed in a one-stage surgical procedure [20]. Originally, they were fabricated as transitional implants [21] or for orthodontic anchorage [22], however, their osseointegration outcomes, because of a rough surface, have exhibited to be comparable to conventional dental implants and were then considered as a permanent alternative [17,23-25]. Additional benefits of MDIs include low-cost, less denture bulk, ease of technique, and simple surgical procedures without bone augmentation [26]. A few drawbacks are also associated with MDIs since their mechanical features favor deformation of the ball attachment, implant fracture, and the lack of an anti-rotational notch [6]. A greater incidence of implant fracture has been associated with the use of MDIs as compared to conventional dental implants and has been reported to be sensitive to high-insertion torque [6]. Hence, concern related to possible high fatigue fracture levels associated with MDIs in high-stress regions has resulted in their application is restricted to removable prostheses by many [26].

The previous reports that assessed the MDIs with prosthetic purpose evaluated their viability for retaining single provisional prosthesis in anterior areas, as attachment systems in partial removable dentures, and as support for retaining mandibular overdentures [27-29]. Promising outcomes have been reported so far; however, there is an absence of consensus regarding the utilization of immediate loaded MDIs for retaining mandibular overdentures in the published literature. Some reports have shown high survival rates for MDIs to support mandibular overdentures $[15,30]$ while other reports have demonstrated low survival rates as compared to SDDIs [31]. Hence, this systematic review aimed to verify the feasibility of utilizing immediate loaded MDIs to support mandibular overdentures for permanent prosthetic rehabilitation. The null hypotheses of the present systematic review are stated as follows: (a) the survival rates of immediate loaded MDIs to retain mandibular overdentures are not different compared to SDDIs retaining mandibular overdentures; (b) MDIs retaining mandibular overdentures do not show a compromise in peri-implant clinical and radiographic parameters, quality of life, or patient satisfaction.

\section{Materials and Methods}

The Preferred Reporting Items for Systematic Review and Meta-Analysis (PRISMA) guidelines were followed to carry out the present systematic review [32].

\subsection{Focused Question}

The PICO (Population, Intervention, Comparisons, Outcomes) question formulated was as follow: "Do immediate loaded MDIs supporting mandibular overdentures present favorable treatment option for prosthetic rehabilitation?". The population $(\mathrm{P})$ was subjects rehabilitated using immediate loaded dental implants to retain mandibular overdentures; the intervention (I) was edentulous subjects rehabilitated using mandibular overdentures retained by MDIs; the comparison $(\mathrm{C})$ was edentulous subjects rehabilitated using overdentures retained by SDDIs; the primary outcome $(\mathrm{O})$ was the survival rates of MDIs, while the secondary outcomes were peri-implant clinical (plaque index [PI], gingival index [GI], probing depth [PD], and bleeding on probing [BOP]) as well as radiographic parameters (marginal bone loss [MBL]), along with the quality of life and satisfaction with MDIs where they were utilized to retain mandibular overdentures.

\subsection{Eligibility Criteria}

The inclusion criteria were: (1) randomized controlled/clinical trials, retrospective, case-control, cross-sectional, or cohort studies conducted on adult human subjects involving immediate loaded MDIs for mandibular overdentures; (2) studies published in the English language; and (3) articles published in a peer-reviewed scientific journal.

The exclusion criteria were: (1) studies that did not mention MDIs description as per the definition of GOMI; [19] (2) studies that stated dental implants $>3 \mathrm{~mm}$ in diameter; (3) studies that did not describe the utilization of immediate loaded MDIs for mandibular 
overdentures; (4) studies that did not permit extraction of quantitative data; (5) subjects or clinical information that were redundantly reported in other included studies; (6) case reports/series comprising less than three study participants; and (7) literature review articles.

\subsection{Data Sources, Search Strategy, and Article Selection}

Single investigator performed an independent electronic search of the English literature utilizing Google Scholar, Elsevier's Scopus, Clarivate Analytics' Web of Science, MEDLINE (OVID), EMBASE, and PubMed (National Library of Medicine). The search period ranged from inception up to April 2021. The exact search words were "mini dental implant" OR "mini implant ${ }^{* \prime}$ OR "mini dental implant" AND "overdenture" OR "mini dental implant* AND "prosthodontic*" OR "mini implant" AND "overdenture" OR "mini implant* AND "prosthodontic*".

Manual searching for the studies was conducted by the same investigator until April 2012 in the following journals: Journal of Prosthetic Dentistry, International Journal of Prosthodontics, Journal of Prosthodontics, Journal of Oral Rehabilitation, Journal of Dentistry, Journal of Dental Research, International Journal of Prosthodontics, International Journal of Oral and Maxillofacial Surgery, International Journal of Oral and Maxillofacial Implants, Clinical Oral Implants Research, and Clinical Implant Dentistry and Related Research.

The screening of the abstracts and titles of the articles identified using the abovementioned strategy was conducted by single investigator. A full-text reading of the relevant articles was performed. Manual searching of the bibliography of the pertinent literature reviews and research articles was also carried out for identifying articles that may have been missed in the previous step. Discrepancies were solved via discussion.

\subsection{Data Extraction}

The extraction of data from the included studies was carried out independently by single investigator. The data extracted from the included articles are as follow: (1) author, journal, year, and country of article publication; (2) study design; (3) surgical procedure performed; (4) implant company; (5) length and diameter of dental implants; (6) implant design; (7) number, mean age, and gender of the study participant; (8) total number of dental implants (MDIs and SDDIs) placed; (9) mean scores of clinical and radiographic peri-implant parameters; follow-up period; (11) number of implants failed; (12) survival rate; and (13) study outcome. All the extracted data were cross-checked by the reviewers and any discrepancies were again solved via discussion.

\subsection{Risk of Bias Assessment}

The risk of bias of randomized controlled/clinical trials was evaluated on the basis of the revised guidelines of the Consolidated Standards of Reporting Trials statement. [33] For individual included RCT, the risk of bias was recorded on the basis of the Cochrane Handbook of Systematic Reviews of Interventions [34]. In summary, the following sections were taken into consideration: (a) selection bias (i.e., allocation concealment and randomization); (b) performance bias (i.e., blinding of the research investigator); (c) detection bias (i.e., blinding of outcome assessors); (d) attrition bias (i.e., completeness of follow-up duration); and few other biases. Articles were categorized as "low" (i.e., low risk of bias), "medium" (i.e., medium risk of bias), or "high" (i.e., high risk of bias) for individual sections. Overall, articles were regarded as: (a) "low risk of bias" if all criteria were met; (b) "high risk of bias" if $\geq 1$ criteria were not met; and (c) "medium risk of bias" if $\geq 1$ criteria were partly met.

\subsection{Additional Analysis}

The Kappa statistics was recorded to identify the intra-reader agreement in the article selection method for articles published in all databases as well as for the quality assessment scores of the included studies. The level of inter-reader agreement is almost perfect if the value of kappa is $0.81-1.00$; substantial if kappa is $0.61-0.80$; moderate if kappa is 0.41-0.60; fair if kappa is $0.21-0.40$; and poor if kappa is $<0.20$. The calculation of 
Kappa was performed by assessing the selected abstracts and titles, and later obtaining a score for selected studies on Google Scholar (kappa $=0.91)$, Scopus $(k a p p a=1.00)$, Web of Science $(k a p p a=1.00)$, MEDLINE (kappa $=0.95)$, EMBASE (kappa $=0.89)$, and PubMed (kappa $=0.93)$, indicating a high level of intra-reviewer agreement as per Kappa criteria [35].

\section{Results}

\subsection{Literature Search}

A total of 967 titles were obtained as a result of the search from all electronic databases, out of which only 57 abstracts were suitable for this review. Overall, 16 studies were further considered for full-text review based on the applicability of the exclusion criteria. Further scrutiny led to exclusion of 5 full-text studies, which resulted in an overall 11 articles from which quantitative and qualitative data were gathered for final analysis. The study identification flowchart as per PRISMA is depicted in Figure 1.

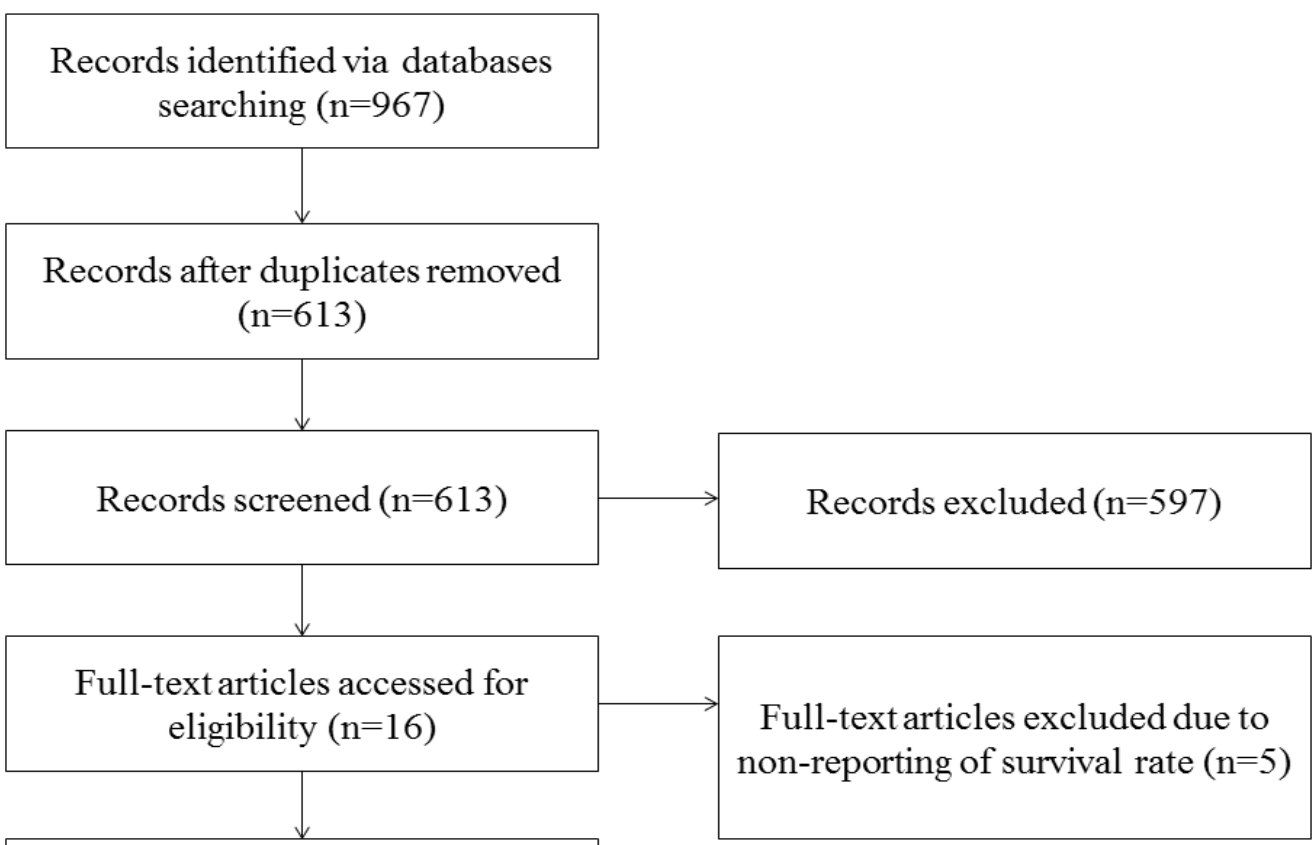

Studies included in the review $(n=11)$

Figure 1. Prisma flow diagram for study methodology.

\subsection{General Description of the Studies}

Of the 11 included articles, 9 were prospective studies [8,17,36-42], while 2 were randomized clinical trials $[43,44]$. For the placement of MDIs, the majority of the articles used full-thickness flaps $(n=5)[8,39,40,43,44]$, followed by flapless technique $(\mathrm{n}=4)[17,36,41,42]$ and minimal thickness flap procedure $(\mathrm{n}=2)[37,38]$. In the included studies, the length and the diameter of MDIs used ranged between 8-18 mm and $1.8-3 \mathrm{~mm}$, respectively. Five studies utilized 1-piece implants $[17,36,39,40,44]$, one study used 2-piece implants [43], while 5 studies did not mention the design of implants used (Table 1) [8,37,38,41,42].

In the included studies, 1190 MDIs and 170 SDDIs were placed in 349 patients [198 males +171 females (range: 8-62 patients)]. The age of participants ranged between 45 and 86 years ( $66.65 \pm 6.28$ years). A wide variation was noticed regarding the implant follow-up durations, with the lowest being 12 months and the highest being 60 months after implant surgery (Table 2). 
Table 1. Summary of qualitative data of the 11 included articles on immediately loaded mini dental implants to retain mandibular overdentures

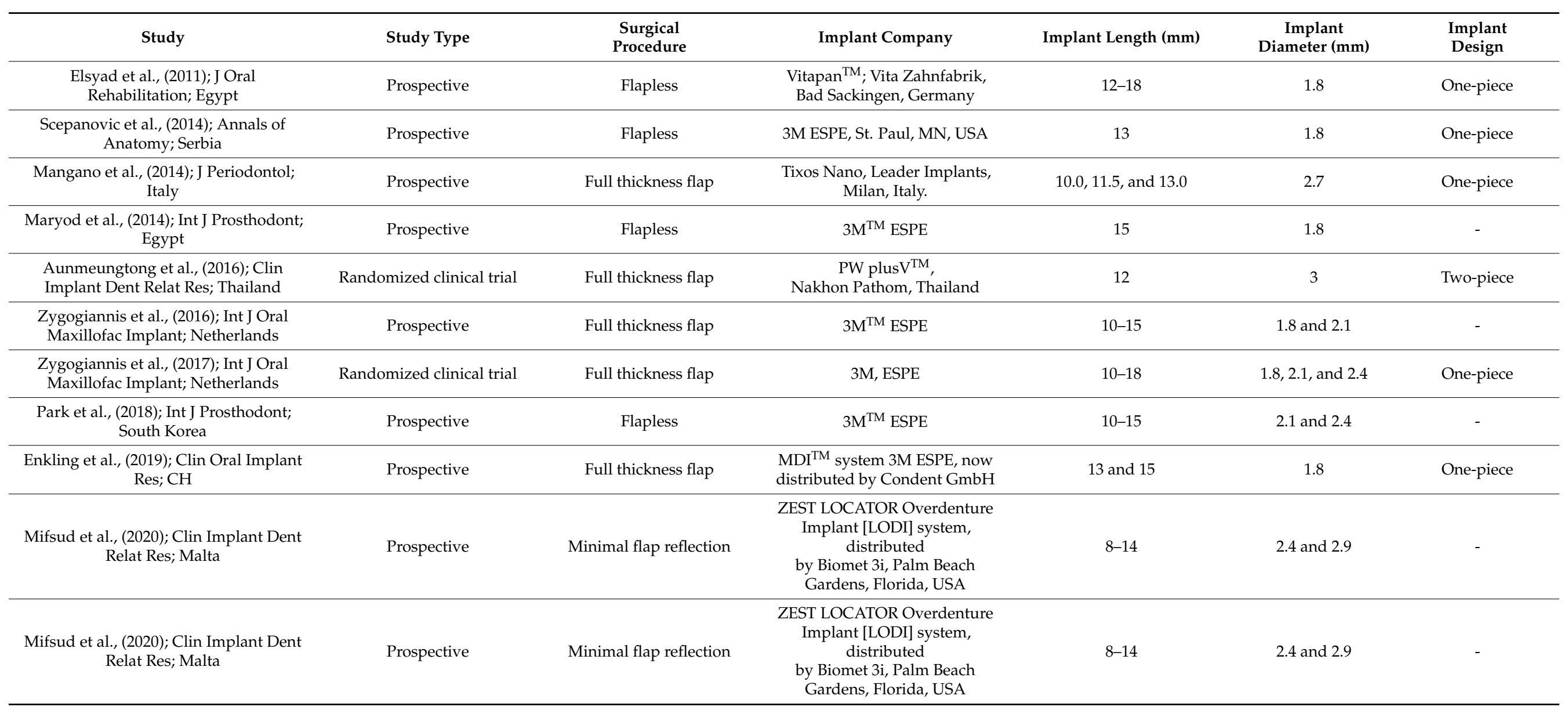


Table 2. Summary of quantitative data of the 11 included articles on immediately loaded mini dental implants to retain mandibular overdentures.

\begin{tabular}{|c|c|c|c|c|c|c|c|c|}
\hline Study & $\begin{array}{l}\text { Participants (n); } \\
\text { (Male + Female); } \\
\quad \text { Age }\end{array}$ & No. of MDIs (n) & $\begin{array}{c}\text { Follow-Up } \\
\text { (Months) }\end{array}$ & $\begin{array}{c}\text { Peri-Implant } \\
\text { Clinical Parameters }\end{array}$ & $\begin{array}{c}\text { Peri-Implant } \\
\text { Radiographic } \\
\text { Parameters (MBL) }\end{array}$ & $\begin{array}{c}\text { Implants Failed } \\
\text { (n) }\end{array}$ & Survival Rate & Key Outcome \\
\hline $\begin{array}{l}\text { Elsyad et al., } \\
\quad(2011)\end{array}$ & $\begin{array}{c}28(16+12) \\
49-75 \text { years }(62.9 \\
\text { mean) }\end{array}$ & 112 & 36 & $\begin{array}{c}\text { PI: } 2(0-3) \\
\text { GI: } 1(0-3) \\
\text { PD: } 1.39 \pm 0.39 \mathrm{~mm}\end{array}$ & $1.26 \pm 0.64 \mathrm{~mm}$ & 4 & $96.4 \%$ & $\begin{array}{l}\text { Clinical and radiographic peri-implant tissue } \\
\text { responses of immediately loaded MDIs } \\
\text { supporting a mandibular overdenture were } \\
\text { favourable after } 3 \text { years. }\end{array}$ \\
\hline $\begin{array}{l}\text { Scepanovic et al., } \\
\text { (2014) }\end{array}$ & $\begin{array}{c}30(14+16) ; \\
45 \text { to } 63 \text { years }\end{array}$ & MDIs: 120 & 12 & - & - & 2 & $98.3 \%$ & $\begin{array}{l}\text { MDIs placed into the interforaminal region } \\
\text { could achieve a favorable primary stability for } \\
\text { immediate loading. } \\
\text { The 1-year bone resorption around } \\
\text { immediately loaded MDIs is within the } \\
\text { clinically acceptable range for } \\
\text { standard implants. }\end{array}$ \\
\hline $\begin{array}{c}\text { Mangano et al., } \\
\text { (2014) }\end{array}$ & $\begin{array}{l}62(38+24) \\
62-86 \text { years }(71.1 \\
\text { mean })\end{array}$ & 231 & 48 & - & $0.62 \pm 0.20 \mathrm{~mm}$ & 6 & $96.9 \%$ & $\begin{array}{l}\text { Immediate loading one 1-piece, unsplinted, } \\
\text { titanium MDIs by means of ball-attachment } \\
\text { supported mandibular overdentures is a } \\
\text { successful treatment procedure. }\end{array}$ \\
\hline $\begin{array}{l}\text { Maryod et al., } \\
\text { (2014) }\end{array}$ & $\begin{array}{c}36(20+16) ; \\
63.4 \text { years (mean) }\end{array}$ & 120 & 36 & $\begin{array}{l}\text { PI: } 1.688 \\
\text { PD: } 1.203 \\
\text { BOP: } 1.313\end{array}$ & $1.17 \pm 0.65 \mathrm{~mm}$ & 7 & $94.2 \%$ & $\begin{array}{l}\text { Immediate and early loading protocols } \\
\text { demonstrated good clinical outcomes with } \\
\text { favourable peri-implant tissue response } 3 \\
\text { years after implant placement. } \\
\text { Early loading of MDIs supporting a } \\
\text { mandibular overdenture seemed to be } \\
\text { preferable to immediate loading. }\end{array}$ \\
\hline $\begin{array}{l}\text { Aunmeungtong } \\
\text { et al., (2016); }\end{array}$ & $\begin{array}{c}60(34+26) \\
69.2 \pm 11.2 \text { years }\end{array}$ & $\begin{array}{l}60 \text { (2-MDIs: } 20+ \\
\text { 4-MDIs: } 20+ \\
\text { SDDIs: 20) }\end{array}$ & 12 & - & - & 0 & $100 \%$ & $\begin{array}{l}\text { Two and four MDIs can be immediately used } \\
\text { successfully for retaining lower complete } \\
\text { dentures, as shown after a 1-year follow up. }\end{array}$ \\
\hline $\begin{array}{l}\text { Zygogiannis } \\
\text { et al., (2016) }\end{array}$ & $\begin{array}{c}8(6+2) \\
70.6 \text { years }(\text { mean })\end{array}$ & 110 & 18 & - & $1.05 \pm 0.81 \mathrm{~mm}$ & 0 & $100 \%$ & $\begin{array}{l}\text { The short-term radiographic peri-implant } \\
\text { bone level changes of MDIs immediately } \\
\text { loaded with overdentures in the edentulous } \\
\text { mandible were within physiological limits. } \\
\text { The patients expressed a high level of } \\
\text { satisfaction and OHrQoL with this } \\
\text { treatment modality. }\end{array}$ \\
\hline
\end{tabular}


Table 2. Cont

\begin{tabular}{|c|c|c|c|c|c|c|c|c|}
\hline Study & $\begin{array}{l}\text { Participants (n); } \\
\text { (Male + Female); } \\
\text { Age }\end{array}$ & No. of MDIs (n) & $\begin{array}{l}\text { Follow-Up } \\
\text { (Months) }\end{array}$ & $\begin{array}{c}\text { Peri-Implant } \\
\text { Clinical Parameters }\end{array}$ & $\begin{array}{c}\text { Peri-Implant } \\
\text { Radiographic } \\
\text { Parameters (MBL) }\end{array}$ & $\begin{array}{l}\text { Implants Failed } \\
\text { (n) }\end{array}$ & Survival Rate & Key Outcome \\
\hline $\begin{array}{l}\text { Zygogiannis } \\
\text { et al., (2017) }\end{array}$ & $\begin{array}{c}50(24+26) \\
67.9 \pm 7.7 \text { years }\end{array}$ & $\begin{array}{l}150 \text { (MDIs: } 100+ \\
\text { SDDIs: 50) }\end{array}$ & 12 & $\begin{array}{l}\text { PI: } 0.43 \pm 0.71 \\
\text { PD: } 1.76 \pm 0.43 \\
\text { BOP: } 0.32 \pm 0.38\end{array}$ & $0.42 \pm 0.56 \mathrm{~mm}$ & 2 & $98 \%$ & $\begin{array}{c}\text { Immediate loading of four unsplinted MDIs } \\
\text { or two splinted SDDIs to retain mandibular } \\
\text { overdentures appeared to be a feasible } \\
\text { treatment option } \\
\text { The marginal bone level changes around the } \\
\text { MDIs were well within clinically } \\
\text { acceptable range. }\end{array}$ \\
\hline $\begin{array}{l}\text { Enkling et al., } \\
\text { (2019) }\end{array}$ & $\begin{array}{c}25(5+15) ; \\
41-87 \text { years }(65.5 \\
\text { median) }\end{array}$ & 80 & 60 & - & - & 0 & $100 \%$ & $\begin{array}{l}\text { MDIs seem to be a successful treatment } \\
\text { option for edentulous elderly patients with } \\
\text { very high survival and success rates, and } \\
\text { serve to improve long-term oral function. }\end{array}$ \\
\hline $\begin{array}{l}\text { Mifsud et al., } \\
\quad(2020)\end{array}$ & $\begin{array}{c}50(25+25) \\
66.8 \pm 8.1 \text { years }\end{array}$ & $\begin{array}{l}100 \text { (MDIs: } 50 \\
\text { + SDDIs: 50) }\end{array}$ & 12 & - & - & $\begin{array}{l}\text { SDDIs: } 1 \\
\text { MDIs: } 3\end{array}$ & $94 \%$ & $\begin{array}{l}\text { Mandibular overdentures retained by two } \\
\text { SDDIs or MDIs lead to a significant and } \\
\text { comparable improvements in OHrQoL and } \\
\text { satisfaction over a 1-year follow-up. }\end{array}$ \\
\hline
\end{tabular}

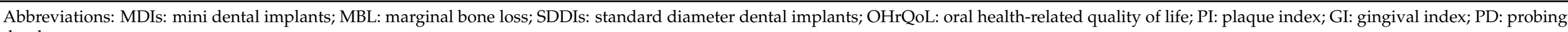
depth. 
The groups of investigated participants varied as per the study type; seven studies were conducted using MDIs only [8,17,36,39,40,42,44]; three studies compared the utilization of MDIs with SDDIs [37,38,43]; and one study compared the outcomes of immediate with early loaded MDIs to retain mandibular overdentures [41].

\subsection{Primary and Secondary Outcome Analysis}

A total of 32/1190 MDIs (2.7\%) failed with a cumulative survival rate of $97.3 \%$ (survival rate range: 94-100\%). The peri-implant clinical (plaque index [PI], gingival index [GI], probing depth $[\mathrm{PD}]$, and bleeding on probing $[\mathrm{BOP}]$ ) and radiographic (marginal bone loss [MBL]) parameters were reported by 3 and 6 studies, respectively. Regarding MBL, 5 out of the 6 included studies reported the utilization of different indexing techniques to attach the film-holder for obtaining reproducible images of marginal bone levels on subsequent follow-ups including self-cure acrylic resin [17], polyvinyl siloxane [40,41], distance (mm) from the polished transgingival collar of the implant to the first crestal bone-to-implant contact [8], and light-cure acrylic resin [44]. The mean scores of PI, GI, PD, and BOP ranged between $0-3,0-3,1.203-1.76$ respectively, whereas the mean MBL values ranged from $0.42 \pm 0.56 \mathrm{~mm}$ to $1.26 \pm 0.64 \mathrm{~mm}$ (Table 2).

\subsection{Key Outcomes}

The majority of the studies reported that the immediate loading of MDIs to retain mandibular overdentures seemed to be a feasible treatment option for edentulous patients with a high survival rate. Additionally, studies reported that peri-implant clinical and radiographic tissue responses of immediate loaded MDIs for retaining mandibular overdentures were well within clinically physiological limits at the subsequent follow-ups. According to a study, the number of prosthetic complications is not affected by the diameter of the dental implant, and the loosening of the abutment is a predisposing factor for overdenture fractures, irrespective of the dental implant diameter utilized. One study reported that the application of MDIs having wider diameters demonstrated higher initial stability as compared to those having narrow diameters, which might affect implant survival. Another study concluded that early loading of MDIs supporting a mandibular overdenture appeared to be a preferable option to immediate loading.

\subsection{Impact of MDIs on Quality of Life and Satisfaction}

Out of 11 includes articles, only 3 studies assessed the quality of life/degree of satisfaction of patients post prosthetic therapy with MDIs $[8,38,43]$. The indices described by these studies are as follow (1) Oral Health Impact Profile (OHIP-14); (2) Denture Satisfaction Questionnaire (DSQ); (3) Visual Analogue Scale Satisfaction (VAS); and (4) Oral Health-Related Quality of Life (OHRQoL). The chewing efficacy was reportedly unchanged using immediate loaded MDIs to retain mandibular overdentures at 1-year follow-up, however, it was enhanced at 5-year follow-up. Moreover, a constant increase in the maximum voluntary bite force (MBF) was observed over time. Additionally, a high level of OHRQoL and satisfaction was expressed by the patients receiving this treatment modality.

\subsection{Risk of Bias/Quality Assessment}

In the qualitative analysis, quality assessment exhibited a wide variety across the included articles (Table 3). Four studies demonstrated a low risk of bias [8,41,42,44], two studies showed medium risk of bias [39,43], and five studies exhibited high risk of bias $[17,36-38,40]$. Therefore, a high risk of bias was observed for the included studies. 
Table 3. Quality assessment of studies included in the systematic review.

\begin{tabular}{|c|c|c|c|c|c|c|c|c|c|c|}
\hline Study & $\mathbf{R}$ & B & $\begin{array}{c}\text { Clear and } \\
\text { Appropriate Focused } \\
\text { Study Question }\end{array}$ & $\begin{array}{c}\text { Identical } \\
\text { Treatment Except } \\
\text { for Intervention }\end{array}$ & $\begin{array}{l}\text { Defined } \\
\text { Eligibility } \\
\text { Criteria }\end{array}$ & $\begin{array}{l}\text { Sufficient } \\
\text { Number of } \\
\text { Implants }\end{array}$ & $\begin{array}{l}\text { Follow-Ups Completed/ } \\
\text { Dropouts/Reason for } \\
\text { Dropout (Yes/No) }\end{array}$ & $\begin{array}{l}\text { Conflict of } \\
\text { Interest Stated }\end{array}$ & Funding Source & Risk of Bias \\
\hline $\begin{array}{l}\text { Elsyad et al., } \\
\text { (2011) }\end{array}$ & No & No & Yes & Yes & Yes & Yes & Yes & No & No & High \\
\hline $\begin{array}{l}\text { Scepanovic } \\
\text { et al., (2014) }\end{array}$ & No & No & Yes & Yes & Yes & Yes & Yes & No & No & High \\
\hline $\begin{array}{l}\text { Mangano et al., } \\
\text { (2014) }\end{array}$ & No & No & Yes & Yes & Yes & Yes & Yes & Yes & No & High \\
\hline $\begin{array}{l}\text { Maryod et al., } \\
\text { (2014) }\end{array}$ & Yes & Yes & Yes & Yes & Yes & Yes & Yes & Yes & No & Low \\
\hline $\begin{array}{l}\text { Aunmeungtong } \\
\text { et al., (2016) }\end{array}$ & Yes & Yes & Yes & Yes & Yes & Yes & Yes & No & No & Medium \\
\hline $\begin{array}{l}\text { Zygogiannis } \\
\text { et al., (2016) }\end{array}$ & Yes & No & Yes & Yes & Yes & Yes & Yes & Yes & Yes & Low \\
\hline $\begin{array}{l}\text { Zygogiannis } \\
\text { et al., (2017) }\end{array}$ & Yes & No & Yes & Yes & Yes & Yes & Yes & Yes & Yes & Low \\
\hline $\begin{array}{l}\text { Park et al., } \\
\text { (2018) }\end{array}$ & Yes & No & Yes & Yes & Yes & Yes & Yes & Yes & Yes & Low \\
\hline $\begin{array}{l}\text { Enkling et al., } \\
\text { (2019) }\end{array}$ & No & No & Yes & Yes & Yes & Yes & Yes & Yes & Yes & Medium \\
\hline $\begin{array}{l}\text { Mifsud et al., } \\
\quad(2020)\end{array}$ & No & No & Yes & Yes & Yes & Yes & Yes & Yes & No & High \\
\hline $\begin{array}{l}\text { Mifsud et al., } \\
(2020)\end{array}$ & Yes & No & Yes & Yes & Yes & Yes & Yes & No & No & High \\
\hline
\end{tabular}

Abbreviations: B: blinding; R: randomization. 


\section{Discussion}

The present systematic review aimed to investigate the survival rate of immediate loaded MDIs to retain mandibular overdentures in edentulous patients. Although MDIs were introduced around 15 years ago, however, there is a dearth of published studies regarding implant/prosthodontic literature [13]. Moreover, only four articles reported a follow-up duration of $\geq 3$ years. Additionally, relatively low sample size was observed in the majority of the included studies. Furthermore, no study compared the MDIs with narrow diameter dental implants, while only four studies compared the MDIs with SDDIs for fixed prosthodontic therapy. In addition, no study described the application of immediate loaded MDIs to retain maxillary overdentures. Contrarily, a few reports on the application of MDIs for orthodontic therapy were observed [45-47]. This might be due to the short duration that MDIs are utilized in orthodontic treatment; this aids in designing the study.

In the current review, NDDIs were not considered to be included in order to perform a more targeted search. This explicit differentiation between MDIs and NDDIs was made to resolve all possible ambiguities. The GOMI definition of MDIs and threshold of $>3 \mathrm{~mm}$ implant diameter was applied [48]. As no previous consensus reports or clinical studies have differentiated between these two kinds of dental implants, we selected the GOMI definition of MDIs in combination with a threshold of $>3 \mathrm{~mm}$ implant diameter. According to the authors of the present review, a dental implant having a diameter of $\leq 3 \mathrm{~mm}$ is best considered to be an MDI, which is considerably different from NDDI. This adoption of the GOMI definition and $3 \mathrm{~mm}$ implant diameter threshold is recommended for future studies on MDIs.

The hypothesis has been accepted since this systematic review reported a high survival rate $(97.3 \%)$ for immediate loaded MDIs for retaining mandibular overdentures, and this survival outcome was comparable to those using SDDIs to retain overdenture prosthesis $[49,50]$. These outcomes suggest that MDIs for mandibular overdentures might become a feasible therapeutic technique, particularly for patients having limitations including financial constraints because SDDIs need a particular retention system for retaining prostheses (i.e., bar-clip, $\mathrm{ERA}^{\mathrm{TM}}, \mathrm{O}^{\prime}$ ring), while MDIs are mostly single-body dental implants including the ball system. Furthermore, postoperative morbidity is decreased by using MDIs in patients who are unable to be subjected to extensive surgical procedures; in the majority of instances, the installation of MDIs is carried out without the utilization of surgical flaps $[30,51]$.

Generally, the overall survival rate of immediate loaded MDIs for retaining mandibular overdentures is favorable as reported by the outcomes of the present review. Of the included studies, four studies compared the utilization of MDIs with SDDIs. According to two reports conducted by Mifsud et al. [37], lower survival rates were exhibited by MDIs in comparison with SDDIs, i.e., one SDDI failed (98\%), while three MDIs failed (94\%). Similarly, according to Zygogiannis et al. [8], MDIs showed lower survival rates as compared to SDDIs, i.e., two MDIs failed (98\%), while no SDDI failed (100\%). In the present study, a higher survival rate ( $>96 \%$ ) was observed by utilizing longer MDIs (10-18 $\mathrm{mm}$ ) as compared to shorter MDIs $(8-14 \mathrm{~mm})(<95 \%)$. Similar outcomes were noticed in a study reported by Tomasi et al. [52], according to which MDIs having a short length (7-10 $\mathrm{mm})$ exhibited a higher failure rate as compared to longer MDIs (14 mm). Hence, the longevity of MDIs might be affected by their length, and longer MDIs should be chosen for better treatment outcomes.

Of the 11 included articles, nine were prospective studies, while two were clinical trials. A variable reporting method on MDIs' follow-up was observed in several studies, which led to a challenging quantitative data extraction as follow: (a) most studies reported a wide follow-up duration (i.e., between 12 months and 60 months); (b) the majority of studies failed to report the number of implants followed during a particular interval of time and did not mention the timing of implant failure; (c) the majority of studies reported follow-up durations of $<3$ years; $(d)$ most of the studies $(n=6)$ described a follow-up duration of 12 months only, indicating that the long-term survival rate of MDIs is unknown; 
and (3) only one study described the life table survival analysis with an interval survival rate and cumulative survival rate of $94.7 \%$ each. It is essential to note that the 1 st year interval survival rate of $94.7 \%$ does not indicate the one-year true survival rate of MDIs, since not all MDIs had a minimum follow-up duration of 12 months.

McGill consensus suggests the utilization of two SDDIs for retaining mandibular overdentures [53]. With regards to the application of MDIs, most of the articles included in the present review utilized four MDIs for retaining mandibular overdentures, whereas two articles utilized two MDIs, and only one study utilized both two and four MDIs. On assessing the effect of the number of MDIs in the same article [43], higher prosthetic complications were observed for the utilization of two MDIs $(n=64)$ as compared to four MDIs $(n=52)$. Moreover, the findings of the present review suggest that four MDIs are linked with higher rates of patient satisfaction and quality of life. Hence, the use of four MDIs might be recommended to retain mandibular overdentures for prosthetic rehabilitation.

The findings of the included studies in the present review report that the MBL was well within clinically physiological limits [54], and no study reported an MBL of $\geq 1.5 \mathrm{~mm}$. It is imperative to notice that this review examined bone loss scores in the mandibular arch, and this might have affected this variation. Hence, further studies following subjects over longer durations to assess MBL in both the maxillary and mandibular arch should be carried out to compare the bone loss of MDIs with SDDIs.

Regarding the surgical technique, most of the studies used the full-thickness flap technique for the placement of MDIs (45.45\%), followed by the flapless technique (36.36\%). Some authors recommend the use of a flapless procedure since it might decrease discomfort, postoperative pain, and resultantly reducing the morbidity of patients $[13,17,29]$. However, Ribeiro and colleagues [51] compared the flap technique with the flapless technique for installing SDDIs and observed no difference with regards to postoperative morbidity and/or pain.

One of the limitations of this systematic review is the inclusion of the studies published in English language only. Although, there has been a remarkable increase in the number of studies that have examined the behavior of immediate loaded MDIs to retain mandibular overdentures, however, there are a very limited amount of randomized controlled/clinical trials. Moreover, the challenge of blinding the research investigators, participants, and outcome assessors might be regarded as a bias of this review. Therefore, caution should be taken while interpreting the outcomes of this study because of lower number of randomized controlled/clinical trials, and further clinical trials should be conducted to better answer in regards to rehabilitation therapy using mandibular overdentures retained by MDIs. Despite this, the utilization of immediate loaded MDIs for retaining mandibular overdentures exhibits viability, high patient satisfaction and quality of life, adequate survival rates, and clinically acceptable peri-implant clinical and radiographic parameters.

\section{Conclusions}

Within the boundaries of the present systematic review, the utilization of immediate loaded MDIs to retain mandibular overdentures is an alternative treatment modality as it demonstrates high survival rates of MDIs, favorable peri-implant clinical and radiographic tissue response, and enhancements in parameters associated with quality of life and satisfaction of patients.

Funding: Author would like to thank the College of Dentistry Research Center and Deanship of Scientific Research at King Saud University, Saudi Arabia for funding this research project.

Institutional Review Board Statement: No need it's a systematic review.

Informed Consent Statement: Not applicable.

Data Availability Statement: The data is available on contact from the corresponding author. 
Acknowledgments: I would like to acknowledge the statistician at college of dentistry King Saud University for helping in the project. Author would like to thank the College of Dentistry Research Center and Deanship of Scientific Research at King Saud University, Saudi Arabia for funding this research project.

Conflicts of Interest: The author declares no conflict of interest.

\section{References}

1. Goiato, M.C.; Filho, H.G.; Dos Santos, D.M.; Barao, V.A.R.; Junior, A.C. Insertion and follow up of complete dentures: A literature review. Gerodontology 2011, 28, 197-204. [CrossRef] [PubMed]

2. Goiato, M.C.; Bannwart, L.C.; Moreno, A.; dos Santos, D.M.; Martini, A.P.; Pereira, L.V. Quality of life and stimulus perception in patients' rehabilitated with complete denture. J. Oral Rehabil. 2012, 39, 438-445. [CrossRef] [PubMed]

3. Goiato, M.C.; Sonego, M.V.; dos Santos, D.M.; da Silva, E.V. Implant rehabilitation in bruxism patient. BMJ Case Rep. 2014, 2014, bcr2014204080. [CrossRef] [PubMed]

4. Feine, J.S.; Carlsson, G.E.; Awad, M.A.; Chehade, A.; Duncan, W.J.; Gizani, S.; Head, T.; Lund, J.P.; MacEntee, M.; Mericske-Stern, R.; et al. The McGill Consensus Statement on Overdentures. Montreal, Quebec, Canada. May 24-25, 2002. Int. J. Prosthodont. 2002, 15, 413-414.

5. Peršić, S.; Ćelić, R.; Vojvodić, D.; Petričević, N.; Kranjčić, J.; Zlatarić, D.K.; Čelebić, A. Oral Health-Related Quality of Life in Different Types of Mandibular Implant Overdentures in Function Longer Than 3 Years. Int. J. Prosthodont. 2016, $29,28-30$. [CrossRef]

6. Schwindling, F.S.; Schwindling, F.P. Mini dental implants retaining mandibular overdentures: A dental practice-based retrospective analysis. J. Prosthodont. Res. 2016, 60, 193-198. [CrossRef] [PubMed]

7. Temizel, S.; Heinemann, F.; Dirk, C.; Bourauel, C.; Hasan, I. Clinical and radiological investigations of mandibular overdentures supported by conventional or mini-dental implants: A 2-year prospective follow-up study. J. Prosthet. Dent 2017, 117, 239-246.e2 [CrossRef]

8. Zygogiannis, K.; Wismeijer, D.; Parsa, A. A pilot study on mandibular overdentures retained by mini dental implants: Marginal bone level changes and patient-based ratings of clinical outcome. Int. J. Oral Maxillofac. Implants 2016, 31, 1171-1178. [CrossRef]

9. Jawad, S.; Barclay, C.; Whittaker, W.; Tickle, M.; Walsh, T. A pilot randomised controlled trial evaluating mini and conventional implant retained dentures on the function and quality of life of patients with an edentulous mandible. BMC Oral Health 2017, 17, 53. [CrossRef]

10. Ahn, M.R.; An, K.M.; Choi, J.H.; Sohn, D.S. Immediate loading with mini dental implants in the fully edentulous mandible. Implant Dent. 2004, 13, 367-372. [CrossRef]

11. Payne, A.G.; Tawse-Smith, A.A.; Thomson, W.M.W.M.; Duncan, W.D.W.D.; Kumara, R.R. One-stage surgery and early loading of three implants for maxillary overdentures: A 1-year report. Clin. Implant Dent. Rel. Res. 2004, 6, 61-74. [CrossRef] [PubMed]

12. Zinsli, B.; Sägesser, T.; Mericske, E.; Mericske-Stern, R. Clinical evaluation of smalldiameter ITI implants: A prospective study. Int. J. Oral Maxillofac. Implants 2004, 19, 92-99.

13. Bidra, A.S.; Almas, K. Mini implants for definitive prosthodontic treatment: A systematic review. J. Prosthet. Dent. 2013, 109, 156-164. [CrossRef]

14. ELsyad, M.A.; Ghoneem, N.E.; El-Sharkawy, H. Marginal bone loss around unsplinted mini-implants supporting maxillary overdentures: A preliminary comparative study between partial and full palatal coverage. Quintessence Int. 2013, 44, 45-52.

15. Preoteasa, E.; Imre, M.; Preoteasa, T. A 3-Year Follow-up Study of Overdentures Retained by Mini-Dental Implants. Int. J. Oral Maxillofac. Implants 2014, 29, 1170-1176. [CrossRef] [PubMed]

16. Shatkin, T.E.; Petrotto, C.A. Mini dental implants: A retrospective analysis of 5640 implants placed over a 12-year period. Compendium 2012, 33, 2-9.

17. Elsyad, M.A.; Gebreel, A.A.; Fouad, M.M.; Elshoukouki, A.H. The clinical and radiographic outcome of immediately loaded mini implants supporting a mandibular overdenture. A 3-year prospective study. J. Oral Rehabil. 2011, 38, 827-834. [CrossRef] [PubMed]

18. Mundt, T.; Schwahn, C.; Stark, T.; Biffar, R. Clinical response of edentulous people treated with mini dental implants in nine dental practices. Gerodontology 2015, 32, 179-187. [CrossRef]

19. Laney, W.R. Glossary of Oral and Maxillofacial Implants. Int. J. Oral Maxillofac. Implants 2017, 32, Gi-G200. [CrossRef]

20. Goiato, M.C.; Sônego, M.V.; Pellizzer, E.P.; Gomes, J.M.; da Silva, E.V.; dos Santos, D.M. Clinical outcome of removable prostheses supported by mini dental implants. A systematic review. Acta Odontol. Scand. 2018, 76, 628-637. [CrossRef]

21. Krennmair, G.; Weinländer, M.; Schmidinger, S. Provisional implants for anchoring removable interim prostheses in edentulous jaws: A clinical study. Int. J. Oral Maxillofac. Implants 2003, 18, 582-588.

22. Melsen, B. Mini-implants: Where are we? J. Clin. Orthod. 2005, 39, 539-547.

23. Jofré, J.; Hamada, T.; Nishimura, M.; Klattenhoff, C. The effect of maximum bite force on marginal bone loss of mini-implants supporting a mandibular overdenture: A randomized controlled trial. Clin. Oral Implants Res. 2010, 21, 243-249. [CrossRef]

24. Preoteasa, E.; Meleşcanu-Imre, M.A.R.I.N.A.; Preoteasa, C.T.; Marin, M.; Lerner, H. Aspects of oral morphology as decision factors in mini-implant supported overdenture. Rom. J. Morphol. Embryol. 2010, 51, 309-314. 
25. Balkin, B.E.; Steflik, D.E.; Naval, F. Mini-dental implant insertion with the auto-advance technique for ongoing applications. J. Oral Implantol. 2001, 27, 32-37. [CrossRef]

26. Jawad, S.; Clarke, P.T. Survival of Mini Dental Implants Used to Retain Mandibular Complete Overdentures: Systematic Review. Int. J. Oral Maxillofac. Implants 2019, 34, 343-356. [CrossRef]

27. Hallman, M. A prospective study of treatment of severely resorbed maxillae with narrow nonsubmerged implants: Results after 1 year of loading. Int. J. Oral Maxillofac. Implants 2001, 16, 731-736. [PubMed]

28. Griffitts, T.M.; Collins, C.P.; Collins, P.C. Mini dental implants: An adjunct for retention, stability, and comfort for the edentulous patient. Oral Surg. Oral Med. Oral Pathol. Oral Radiol. Endod. 2005, 100, e81-e84. [CrossRef] [PubMed]

29. Cho, S.; Froum, S.; Tai, C.; Cho, Y.S.; Elian, N.; Tarnow, D.P. Immediate loading of narrowdiameter implants with overdentures in severely atrophic mandibles. Pract. Proced. Aesthet. Dent. 2007, 19, 167-174.

30. Elsyad, M.A. Patient satisfaction and prosthetic aspects with mini-implants retained mandibular overdentures. A 5-year prospective study. Clin. Oral Implants Res. 2016, 27, 926-933. [CrossRef]

31. De Souza, R.F.; Ribeiro, A.B.; Della Vecchia, M.P.; Costa, L.; Cunha, T.R.; Reis, A.C.; Albuquerque, R.F., Jr. Mini vs. standard implants for mandibular overdentures: A randomized trial. J. Dent. Res. 2015, 94, 1376-1384. [CrossRef] [PubMed]

32. Moher, D.; Liberati, A.; Tetzlaff, J.; Altman, D.G. Preferred reporting items for systematic reviews and meta-analyses: The PRISMA statement. Int. J. Surg. 2010, 8, 336-341. [CrossRef]

33. Schulz, K.F.; Altman, D.G.; Moher, D. CONSORT 2010 statement: Updated guidelines for reporting parallel group randomised trials. Trials 2010, 11, 1-8. [CrossRef]

34. Higgins, J.P.; Thomas, J.; Chandler, J.; Cumpston, M.; Li, T.; Page, M.J.; Welch, V.A. Cochrane Handbook for Systematic Reviews of Interventions; John Wiley \& Sons: New York, NY, USA, 2019.

35. Landis, J.R.; Koch, G.G. The measurement of observer agreement for categorical data. Biometrics 1977, 4, 159-174. [CrossRef]

36. Šćepanović, M.; Todorović, A.; Marković, A.; Patrnogić, V.; Miličić, B.; Moufti, A.M.; Mišić, T. Immediately loaded mini dental implants as overdenture retainers: 1-Year cohort study of implant stability and peri-implant marginal bone level. Ann. Anat.-Anat. Anz. 2015, 199, 85-91. [CrossRef]

37. Mifsud, D.P.; Cortes, A.R.; Zarb, M.J.; Attard, N.J. Maintenance and risk factors for fractures of overdentures using immediately loaded conventional diameter or mini implants with Locator abutments: A cohort study. Clin. Implant Dent. Relat. Res. 2020, 22, 706-712. [CrossRef]

38. Mifsud, D.P.; Cortes, A.R.; Attard, N.J. Patient-based outcomes with conventional or mini-implants immediately loaded with locator-retained mandibular overdentures: A cohort study. Clin. Implant Dent. Relat. Res. 2020, 22, 723-729. [CrossRef]

39. Enkling, N.; Haueter, M.; Worni, A.; Müller, F.; Leles, C.R.; Schimmel, M. A prospective cohort study on survival and success of one-piece mini-implants with associated changes in oral function: Five-year outcomes. Clin. Oral Implants. Res. 2019, 30, 570-577. [CrossRef]

40. Mangano, F.G.; Caprioglio, A.; Levrini, L.; Farronato, D.; Zecca, P.A.; Mangano, C. Immediate loading of mandibular overdentures supported by one-piece, direct metal laser sintering mini-implants: A short-term prospective clinical study. J. Periodontol. 2015, 86, 192-200. [CrossRef] [PubMed]

41. Maryod, W.H.; Ali, S.M.; Shawky, A.F. Immediate versus early loading of mini-implants supporting mandibular overdentures: A preliminary 3-year clinical outcome report. Int. J. Prosthod. 2014, 27, 553-560. [CrossRef]

42. Park, J.H.; Shin, S.W.; Lee, J.Y. Two-Step Immediate Loading of Mandibular Overdentures Retained by Mini-implants: A Prospective Clinical Study. Int. J. Prosthod. 2018, 31, 446-450. [CrossRef]

43. Aunmeungtong, W.; Kumchai, T.; Strietzel, F.P.; Reichart, P.A.; Khongkhunthian, P. Comparative clinical study of conventional dental implants and mini dental implants for mandibular overdentures: A randomized clinical trial. Clin. Implant Dent. Rel. Res. 2017, 19, 328-340. [CrossRef] [PubMed]

44. Zygogiannis, K.; Aartman, I.H.; Parsa, A.; Tahmaseb, A.; Wismeijer, D. Implant Mandibular Overdentures Retained by Immediately Loaded Implants: A 1-Year Randomized Trial Comparing the Clinical and Radiographic Outcomes Between Mini Dental Implants and Standard-Sized Implants. Int. J. Oral Maxillofac. Implants 2017, 32, 1377-1388. [CrossRef]

45. Schätzle, M.; Männchen, R.; Zwahlen, M.; Lang, N.P. Survival and failure rates of orthodontic temporary anchorage devices: A systematic review. Clin. Oral Implants Res. 2009, 20, 1351-1359. [CrossRef]

46. Reynders, R.; Ronchi, L.; Bipat, S. Mini-implants in orthodontics: A systematic review of the literature. Am. J. Orthod. Dentofac. Orthop. 2009, 135, 564.e1-e19. [CrossRef]

47. Chen, Y.; Kyung, H.M.; Zhao, W.T.; Yu, W.J. Critical factors for the success of orthodontic mini-implants: A systematic review. Am. J. Orthod. Dentofac. Orthop. 2009, 135, 284-291. [CrossRef]

48. Laney, W.R. GOMI, Glossary of Oral and Maxillofacial Implants; Quintessenz Verlag: Berlin, Germany, 2019.

49. Dantas, I.D.S.; Souza, M.B.C.D.; Morais, M.H.D.S.T.; Carreiro, A.D.F.P.; Barbosa, G.A.S. Success and survival rates of mandibular overdentures supported by two or four implants: A systematic review. Braz. Oral Res. 2014, 28, 74-80.

50. Raghoebar, G.M.; Meijer, H.J.; Slot, W.; Slater, J.J.; Vissink, A. A systematic review of implant-supported overdentures in the edentulous maxilla, compared to the mandible: How many implants. Eur. J. Oral Implantol. 2014, 7, S191-S201.

51. Ribeiro, A.B.; Della Vecchia, M.P.; Cunha, T.R.; Sorgini, D.B.; Dos Reis, A.C.; Muglia, V.A.; de Albuquerque, R.F., Jr.; de Souza, R.F. Short-term post-operative pain and discomfort following insertion of mini-implants for retaining mandibular overdentures: A randomized controlled trial. J. Oral Rehabil. 2015, 42, 605-614. [CrossRef] 
52. Tomasi, C.; Idmyr, B.O.; Wennström, J. Patient satisfaction with mini-implant stabilised full dentures. A 1-year prospective study. J. Oral Rehabil. 2013, 40, 526-534. [CrossRef] [PubMed]

53. Feine, J.S.; Carlsson, G.E.; Awad, M.A.; Chehade, A.; Duncan, W.J.; Gizani, S.; Head, T.; Lund, J.P.; MacEntee, M.; Mericske-Stern, R.; et al. The McGill consensus statement on overdentures. Mandibular two-implant overdentures as first choice standard of care for edentulous patients. Int. J. Oral Maxillofac. Implants 2002, 17, 601-602. [PubMed]

54. Papaspyridakos, P.; Chen, C.J.; Singh, M.; Weber, H.P.; Gallucci, G.O. Success criteria in implant dentistry: A systematic review. J. Dent. Res. 2012, 91, 242-248. [CrossRef] [PubMed] 